\title{
Correlation between leukocyte aggregation score of cerebrospinal fluid and bacterial meningitis in children
}

\author{
Meitha PE Togas, MD; Nurhayati Masloman, MD
}

\begin{abstract}
Background Bacterial meningitis is one of life-threatening diseases and carries a risk of sequelae in affected children. In terms of cost and rapid differentiation between bacterial and non-bacterial meningitis, several tests have been proposed.

Objective This study aimed to determine the use of leukocyte aggregation score (LAS) of cerebrospinal fluid (CSF) in diagnosing bacterial meningitis.

Methods A prospective analytic study was done from October 2001 to July 2002 in the Department of Child Health, Medical School, Sam Ratulangi University/ Manado General Hospital. Children presenting with symptoms of meningitis, aged between 28 days and 13 years were enrolled. LAS was counted in percentage. Regression analysis was used to determine the correlation between LAS and diagnosis of bacterial meningitis.

Results CSF examinations were done on 35 meningitis patients. Three patients were excluded. The remaining 32 patients comprised of 11 with bacterial meningitis and the other 21 with nonbacterial meningitis. The mean of LAS in bacterial meningitis was significantly higher than that of non-bacterial meningitis $(p<0.001)$. The cut off value of LAS to diagnose bacterial meningitis was $12.35 \%$.

Conclusion LAS may be used as a fast and simple alternative diagnostic tool to confirm the diagnosis of bacterial meningitis [Paediatr Indones 2004;44:61-65].
\end{abstract}

Keywords: bacterial meningitis, leukocyte aggregation score, cerebrospinal fluid

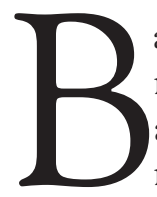

acterial meningitis is one of life-threatening neurologic diseases, especially in neonatal and childhood, that carries a high risk of neurologic sequelae and still has high mortality. ${ }^{1-3}$ Early diagnosis and prompt treatment are important in the management of bacterial meningitis. But early symptoms and signs are not specific, mainly in infant. There had been no single examination that could early distinguish the etiology of meningitis in infant and children. ${ }^{1-3}$ Yet, there are many reports about the efforts to diagnose bacterial meningitis as early as possible, such as CSF lactate level, ${ }^{4} \mathrm{C}$-reactive protein (CRP),,$^{5-7}$ lactoferrin, $\alpha-1$ antitrypsin, immunoglobulin GA, ${ }^{7}$ tumor necrosis factor (TNF), ${ }^{8-}$ 10 interleukin (IL) $1 \alpha,,^{10-11}$ IL-6, ${ }^{12}$ granulocyte colony stimulating factor, ${ }^{13}$ bacterial antigen detection test, ${ }^{14}$ and CSF leukocyte aggregation score (LAS). ${ }^{15-16}$ CSF LAS examination is simple, fast, not expensive, and does not need sophisticated equipment or skills. ${ }^{16}$

The objective of this study was to evaluate the use of LAS examination in establishing early diagnosis of bacterial meningitis and to compare it with standard examinations.

\section{Methods}

A prospective analytic study was conducted at the Department of Child Health, Manado General Hospital from October 2001 to July 2002. The inclusion criteria were infants and children aged between 28 days and 13 years with symptoms and signs

\footnotetext{
From the Department of Child Health, Medical School, Sam Ratulangi University, Manado General Hospital, Manado.
}

Reprint requests to: Nurhayati Masloman, MD, Department of Child Health, Medical School, Sam Ratulangi University, Manado General Hospital, Manado, Indonesia. Tel. 62-431-821652, Fax. 62-431-859091, Email: ikarsup@wasantara.net 
of meningitis who were admitted to our department. The exclusion criteria were infants or children who had contraindication of lumbar puncture (LP) (shock, severe general condition, skin infection around the location of LP, space occupying lesion, hydrocephalus, blood dyscrasia, hyperventilation, irregular respiration, and apnea), blood-contaminated CSF whether grossly or microscopically, and other conditions such as meningismus, malignancy, collagen-vascular syndromes, toxin exposure, and focal infection of the central nervous system (i.e., brain abscess, parameningeal infection, and subdural empyema). Informed consent was obtained from the parents.

The diagnosis of bacterial meningitis is based on symptoms and signs of meningitis i.e., fever, seizure, and unconsciousness, plus at least one of the followings: 1) biochemistry and cytology results of CSF examination were opalescent to turbid in color, Nonne $(+)$, Pandy $(+)$, protein $>40 \mathrm{mg} / \mathrm{dL}$, glucose $<40$ $\mathrm{mg} / \mathrm{dL}$, leukocyte count $1,000-10,000 / \mathrm{mm}^{3}$ with predominant PMN, and positive Gram staining; 2) positive bacterial growth on culture.

After LP had been performed, the CSF obtained was divided into 2 tubes. One tube containing 1-2 $\mathrm{mL}$ CSF was sent to Prodia Clinical Laboratory for biochemistry, cytology, and Gram staining examination within 90 minutes. The second one containing 1 $\mathrm{mL}$ CSF was sent as soon as possible to the Department of Microbiology, Medical School, Sam Ratulangi University for bacterial culture. The procedure to make LAS slide was as follows: one to two drops of CSF was put on an object glass, then it was laid on a $45^{\circ}$ declined base for 3-4 seconds. The CSF was precipitated by gravitation, leaving a thin layer. Then, it was dried on a horizontal position, fixed by absolute methanol and stained with hematoxyllin-eosin. Two skillful pathologists from the Department of Clinical Pathology, Medical School, Sam Ratulangi University, read it under a light microscopes without knowing either the patient's condition or the results of CSF biochemistry, cytology, and culture. The score was then given in percentage.

Data were analyzed descriptively and analytically. Regression model was used to determine the correlation between two variables, with formula: $\mathrm{y}=\mathrm{Bx}+\mathrm{E}$ (y for dependent variable i.e., diagnosis of bacterial meningitis; $\mathrm{x}$ for independent variable, i.e., LAS; $\mathrm{B}$ for regression coefficient; and $\mathrm{E}$ for other variable).
Fisher's exact test was used to compare two categorical variables.

\section{Results}

From October 2001 to July 2002, CSF examinations were conducted on 35 patients with symptoms and signs of meningitis who were admitted to the Department of Child Health, Medical School, Sam Ratulangi University, Manado General Hospital. Three patients were excluded due to technical faults i.e., one without Pandy and protein level examination results, one with biochemistry, cytology, and Gram staining examination performed in more than 90 minutes after LP, and the other one with insufficient CSF sample for bacterial culture. The remaining 32 patients comprised of 11 patients with bacterial meningitis and 21 with non-bacterial meningitis.

The characteristics of the patients showed that most were in the age of $<2$ year-old. The ratio of male to female was 1:1.

Table 1 shows that positive bacterial culture was found mostly in the age of $<2$ years ( 6 from 11 patients).

Table 1. Distribution of patients With positive culture RESULTS ACCORDING TO BACTERIAL ETIOLOGY AND AGE GROUP

\begin{tabular}{lllll}
\hline Bacterial etiology & \multicolumn{4}{l}{ Age Group } \\
\cline { 2 - 5 } & $<\mathbf{2}$ yrs & $\mathbf{2 - 5}$ yrs & > 5 yrs & Total \\
\hline Enterobacter aerogenes & 1 & 2 & 0 & 3 \\
Staphylococcus epidermidis & 3 & 0 & 0 & 3 \\
Alkaligenes faecalis & 0 & 1 & 1 & 2 \\
Citrobacter difersus & 1 & 0 & 0 & 1 \\
Acinetobacter sp. & 0 & 1 & 0 & 1 \\
Serratia marsecen & 1 & 0 & 0 & 1 \\
\hline Total & $\mathbf{6}$ & $\mathbf{4}$ & $\mathbf{1}$ & $\mathbf{1 1}$ \\
\hline
\end{tabular}

Table 2 shows the mean and standard deviation of age, protein, glucose, leukocyte, and LAS of CSF according to the diagnosis. It was obvious that only the mean of LAS that was significantly higher in bacterial meningitis than that in non-bacterial meningitis $(\mathrm{p}<0.001)$.

The correlation between diagnosis and the results of CSF examinations including biochemistry, cytology, and culture is shown in Table 3; only LAS that was significantly correlated to bacterial meningitis. Accord- 
Meitha PE Togas et al: Correlation between leukocyte aggregation score of CSF and bacterial meningitis

Table 2. Mean and standard deviation (SD) of Variables ACCORDING TO DIAGNOSIS.

\begin{tabular}{llll}
\hline \multirow{2}{*}{ Variables } & \multicolumn{2}{c}{ Diagnosis } & \\
\cline { 2 - 3 } & $\begin{array}{l}\text { Bacterial } \\
\text { Meningitis } \\
\text { (mean } \pm \text { SD) }\end{array}$ & $\begin{array}{l}\text { Non-bacterial } \\
\text { Meningitis } \\
\text { (mean } \pm \text { SD) }\end{array}$ & $\mathbf{p}$ \\
\hline Age (years) & $2.77 \pm 2.32$ & $4.06 \pm 3.62$ & 0.296 \\
Protein $(\mathrm{mg} / \mathrm{dL})$ & $247.02 \pm 614.42$ & $52.81 \pm 51.42$ & 0.320 \\
Glucose $(\mathrm{mg} / \mathrm{dL})$ & $40.36 \pm 29.26$ & $59.48 \pm 32.28$ & 0.111 \\
Leukocyte $\left(/ \mathrm{mm}^{3}\right)$ & $377.00 \pm 441.16$ & $100.86 \pm 257.16$ & 0.077 \\
LAS $(\%)$ & $20.27 \pm 8.26$ & $1.95 \pm 3.37$ & 0.000 \\
\hline
\end{tabular}

Table 3. The correlation between CSF examinations and diagnosis

\begin{tabular}{|c|c|c|c|c|}
\hline \multirow[b]{2}{*}{ CSF examinations } & \multicolumn{2}{|c|}{ Diagnosis } & \multirow[b]{2}{*}{ Total (n) } & \multirow[b]{2}{*}{$\begin{array}{l}\text { Fisher's } \\
\text { exact test }\end{array}$} \\
\hline & $\begin{array}{l}\text { Bacterial } \\
\text { meningitis } \\
\text { (n) }\end{array}$ & $\begin{array}{l}\text { Non-bacterial } \\
\text { meningitis } \\
\text { (n) }\end{array}$ & & \\
\hline Color & & & & $p=0.148$ \\
\hline Turbid & 4 & 2 & 6 & \\
\hline Clear & 7 & 19 & 26 & \\
\hline Nonne test & & & & $p=0.681$ \\
\hline Positive & 4 & 5 & 9 & \\
\hline Negative & 7 & 16 & 23 & \\
\hline Pandy test & & & & $\mathrm{p}=0.645$ \\
\hline Positive & 8 & 12 & 20 & \\
\hline Negative & 3 & 9 & 12 & \\
\hline Protein (mg/dL) & & & & $p=0.703$ \\
\hline$>40$ & 8 & 13 & 21 & \\
\hline$<40$ & 3 & 8 & 11 & \\
\hline Glucose (mg/dL) & & & & $p=0.053$ \\
\hline$<40$ & 7 & 5 & 12 & \\
\hline$>40$ & 4 & 16 & 20 & \\
\hline Leukocyte $\left(/ \mathrm{mm}^{3}\right)$ & & & & $p=0.266$ \\
\hline$>1,000$ & 2 & 1 & 3 & \\
\hline$<1,000$ & 9 & 20 & 29 & \\
\hline Bacterial culture & & & & $p=0.000$ \\
\hline Positive & 11 & 0 & 11 & \\
\hline Negative & 0 & 21 & 21 & \\
\hline LAS (\%) & & & & \\
\hline$>12.35$ & 11 & 0 & 11 & $p=0.000$ \\
\hline$<12.35$ & 0 & 21 & 21 & \\
\hline$>15.0$ & 9 & 0 & 9 & $p=0.000$ \\
\hline$<15.0$ & 2 & 21 & 23 & \\
\hline
\end{tabular}

ing to our equation, the cut off value of LAS for the diagnosis of bacterial meningitis was $12.35 \%$.

\section{Discussion}

In this study, we excluded neonates and we did not perform any culture for Mycobacterium tuberculosis, fungi, and virus; we just categorized the diagnosis as bacterial and non-bacterial meningitis.

Bacterial meningitis was found more frequently in female than male and most commonly at the age of
$<2$ years. These findings were similar to those reported by Klein et al. ${ }^{1}$ Vince et al ${ }^{17}$ reported that bacterial meningitis might occur in all ages, but most frequently in the first year of life.

We did not find bacteria in all Gram staining of CSF. According to literatures, Gram staining may reveal bacteria in about $70 \%$ of bacterial meningitis, but it may show no bacteria if the number of bacteria is less than $10^{4}-10^{5}$ organism $/ \mathrm{ml}$ although the culture shows bacterial growth. ${ }^{18}$

The etiologies of bacterial meningitis in our study were Enterobacter aerogenes and Staphylococcus epidermidis 
(3 patients each), Alkaligenes faecalis (2 patients), Citrobacter difersus, Acinetobacter, and Serratia marcesen (1 patients each). Wenger et al ${ }^{19}$ reported that the etiologies of bacterial meningitis were Enterobacter (9\%), Serratia (9\%), S. epidermidis (8\%), and Acinetobacter (6\%).

Michelow et al $^{16}$ reported that compared to LAS, other CSF examinations (leukocyte count, Gram staining, and culture) and blood culture were less significant in diagnosing bacterial meningitis. In this study, there was no significant correlation between the color of CSF, Nonne/Pandy test, protein, glucose, leukocyte count and the diagnosis of bacterial meningitis. It means that those examinations might not be used as a single diagnostic tool without any additional examinations.

There were only several hundreds of leukocytes per $\mathrm{mm}^{3} \mathrm{CSF}$ in the early stage of bacterial meningitis, even mononuclear cell may be more prominent. ${ }^{20}$ On the other hand, the CSF of non-bacterial meningitis, such as viral or aseptic ones, in their early stage, may be dominated by PMN. ${ }^{20-22}$ Polk et al ${ }^{23}$ reported several cases of bacterial meningitis with normal leukocyte count in their CSF.

Protein level in CSF may vary depending on age, number of cell, etiology, and damaged cells. High protein level may be found in either bacterial meningitis or other conditions. ${ }^{22}$ Thus, we can not confirm the diagnosis of bacterial meningitis based on protein level only.

CSF glucose level may be low in tuberculous meningitis or if sample is examined in more than 90 minutes after LP due to the consumption of glucose by bacteria for their metabolism. The level of glucose in CSF is influenced by blood glucose level. ${ }^{24}$ Thus, it is better to examine both blood and CSF glucose level, and then determine their ratio. It was not done in our study because of our limitation.

There was a very significant correlation between LAS and the diagnosis of bacterial meningitis $(p<0.001)$. Based on these data and by regression analysis model, we found the cutoff value of LAS was $12.35 \%$. Garty et al reported that the cutoff value of LAS was $15 \% .{ }^{15}$

In our study, we found that with the cutoff value of LAS at $12.35 \%$, the sensitivity and specificity were $100 \%$ each. Meanwhile, with the cutoff value at $15 \%$, they were $81.8 \%$ and $100 \%$ respectively. Michelow et $\mathrm{al}^{16}$ reported that the higher the cutoff value, the lower the sensitivity is. They showed the sensitivity of LAS was $92.5 \%-98.5 \%$ and its specificity was $64.3 \%-88.1 \%$. Garty et $\mathrm{al}^{15}$ reported the sensitivity and specificity of LAS to diagnose bacterial meningitis were 88\%-94\% and $100 \%$ respectively.

We concluded that there was a very significant correlation between either LAS or CSF culture and the diagnosis of bacterial meningitis. Therefore LAS may be used as a fast and simple alternative diagnostic tool to confirm the diagnosis of bacterial meningitis.

\section{References}

1. Klein JO, Feigin RD, Mc Cracken GH. Report of the task force on diagnosis and management of meningitis. Pediatrics 1986;78:959-79.

2. Snyder RD. Bacterial and spirochaetal infections of the nervous system. In: Swaiman KF, editor. Pediatric neurology: principles and practice. Toronto: Mosby Co; 1994. p. 611-43.

3. Berkley JA, Mwangi I, Ngetsa J, Mwarumba S, Lowe BS, Marsh K, et al. Diagnosis of acute bacterial meningitis in children at a district hospital in Saharan African. Lancet 2001;357:1753-7.

4. Rutledge J, Benjamin D, Hood L, Smith A. Is the cerebrospinal fluid lactate measurement useful in the management of children with suspected bacterial meningitis? J Pediatr 1981;98:20-4.

5. Coral CJ, Pepple JM, Moxon ER, Hughes WT. C-reactive protein in spinal fluid of children with meningitis. J Pediatr 1981;99:365-9.

6. De Beer FC, Kirsten GF, Gie RP, Beyers N, Strachan AF. Value of $\mathrm{C}$-reactive protein measurement in tuberculous, bacterial and viral meningitis. Arch Dis Child 1984;59:653-6.

7. Gutteberg TJ, Flaegstad T, Jorgensen T. Lactoferrin, C-reactive protein, á-1 antitrypsin and immunoglobulin GA in cerebrospinal fluid in meningitis. Acta Pediatr Scand 1986;75:569-72.

8. Nadal D, Leppert D, Frei K, Lamche H, Fontana A. Tumor necrosis factor-á in infectious meningitis. Arch Dis Child 1989;64:1274-9.

9. Mustafa MM, Ramilo O, Llorens XS, Olsen KD, Magness RR, Mc Cracken GH. Cerebrospinal fluid prostaglandins, interleukin 1-â and tumor necrosis factor in bacterial meningitis. Clinical and laboratory correlations in placebo treated and dexamethasone treated patients. Am J Dis Child 1990;144:883-7. 
10. Lopez-Cortez LF, Cruz-Ruiz M, Gomez-Mateos J, Jimenez-Hernandez D, Palomino J, Jimenez E. Measurement of levels of tumor necrosis factor- $\alpha$ and interleukin $1-\alpha$ in the cerebrospinal fluid of the patients with meningitis of different etiologies: utility in the differential diagnosis. Clin Inf Dis 1993;16:534-9.

11. Ramilo O, Mustafa MM, Porter J, Saez-Lorens X, Mertsola J, Olsen KD, et al. Detection of interleukin $1-\alpha$ but not tumor necrosis factor- $\alpha$ in cerebrospinal fluid of children with aseptic meningitis. Am J Dis Child 1990;144:349-52.

12. Dulkerian SJ, Kilpatrick L, Costarino Jr AT, Mc Cawley L, Fein J, Corcoran J, et al. Cytokine elevations in infants with bacterial and aseptic meningitis. J Pediatr 1995;126:872-6.

13. Shimoda BK, Okamura S, Omori F, Mizuno Y, Hara T, Aoki T, et al. Granulocyte colony-stimulating factor in cerebrospinal fluid from patients with meningitis. Blood 1991;77:2214-7.

14. Bhisitkul DM, Hogan AE, Tanz RR. The role of bacterial antigen detection tests in the diagnosis of bacterial meningitis. Pediatr Emerg Care 1994;10:67-71.

15. Garty B, Berliner S, Liberman E, Danon YL. Cerebrospinal fluid leucocyte aggregation in meningitis. Pediatr Inf Dis J 1997;16:647-51.

16. Michelow IC, Nicol M, Tiemessen C, Chezzi C, Pettifor JM. Value of cerebrospinal fluid leucocyte aggregation in distinguishing the causes of meningitis in children. Pediatr Inf Dis J 2000;19:66-72.

17. Vince J, Biddulph J. Infections of the nervous system. In: Jeliffe DB, editor. Child health in the tropics. A practical handbook for health personnel. $5^{\text {th }}$ ed. USA: ELBS; 1985. p. 148-55.

18. Hashimoto T. Gram stain technique [citated on August 13, 2002]. University Health System. 1995 2000. Available from URL: http://www.meddean. luc.edu/lumen/Deptwebs/microbio/med/gram/ tech.htm.

19. Wenger JD, Hihgtower AW, Facklam RR, Gaventa S, Broome CV. Bacterial meningitis in the United States 1986: report of a multistate surveillance study. J Inf Dis 1990;162:1313-23.

20. Weil ML. Infections of the nervous system. In: Menkes $\mathrm{JH}$, editor. Textbook of child neurology. $4^{\text {th }}$ ed. London: Lea and Febiger; 1990. p. 327-45.

21. Hutchison JH, Cockburn F. Practical pediatric problems. $6^{\text {th }}$ ed. London: Llyod-Luke; 1986. p. 526-34.

22. Haerer AF. De Jong's neurologic examination. $5^{\text {th }}$ ed. Philadelphia: JB Lippincott Co; 1992. p. 777-88.

23. Polk DB, Steele RW. Bacterial meningitis presenting with normal cerebrospinal fluid. Pediatr Inf Dis J 1987;6:1040-2.

24. Menkes JH. The causes of low spinal fluid sugar in bacterial meningitis: another look. Pediatrics 1969;44:1-3. 